\title{
Pink spots on Porites: not always a coral disease
}

Received: 17 September 2009/ Accepted: 6 November 2009/Published online: 26 November 2009

(C) Springer-Verlag 2009
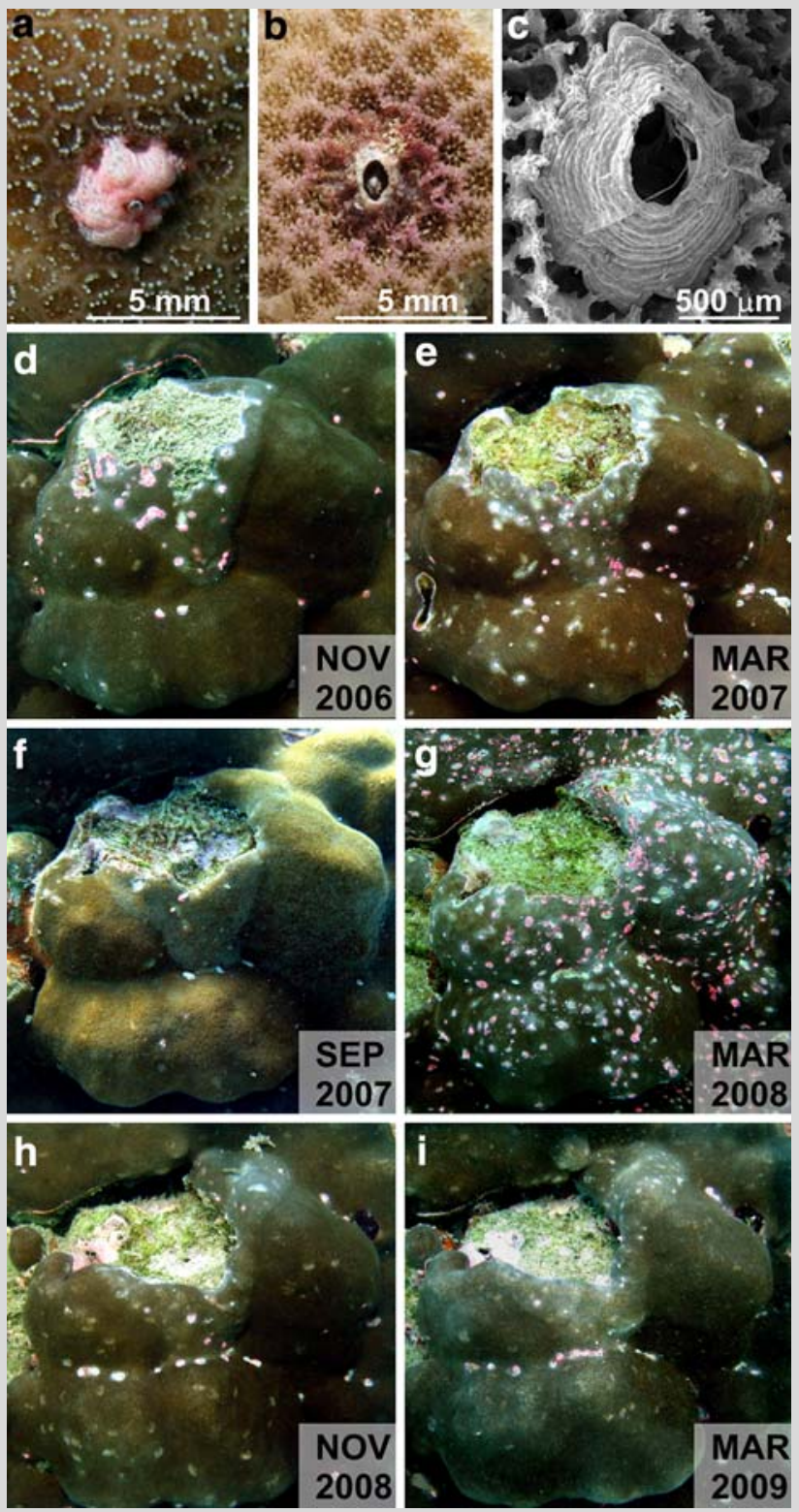

Fig. 1 a A pink spot in vivo showing the swollen coral tissue around the cirriped opening; $\mathbf{b}$ in a dry sample, the tissue coloration persists and the cirriped growing on the coral skeleton is visible; c SEM image of a newly settled cirriped on a $P$. lutea corallite; $\mathbf{d}-\mathbf{i}$ the same photoquadrat $(25-\mathrm{cm}$ side) monitored from November 2006 to March 2009 shows the variations in pink spots density over time, the sampling month and year is indicated at the bottom right
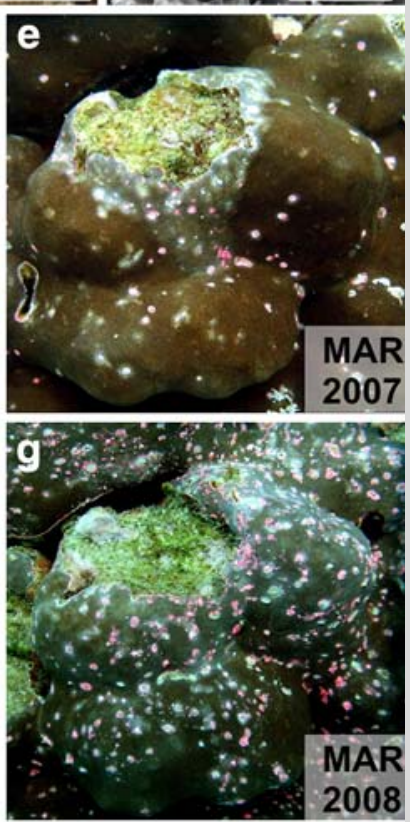

MAR
Aeby G (1993) Corals in the genus Porites are susceptible to infection by a larval trematode. Coral Reefs 22:216

Schuhmacher H (1992) Impact of some corallivorous snails on stony corals in the Red Sea. Proc 7th Int Coral Reef Symp 2:840-6

van Woesik R (1998) Lesion healing on massive Porites spp. corals. Mar Ecol Prog Ser 164:213-22

F. Benzoni $(\bowtie) \cdot$ P. Galli

Department of Biotechnologies and Biosciences, University of Milan-Bicocca, Piazza della Scienza 2, 20126 Milan, Italy e-mail: francesca.benzoni@unimib.it

\section{Pichon}

Museum of Tropical Queensland, 70-102 Flinders Street East, Townsville Qld 4810, Australia 